\title{
Whole-Genome Amplification by Degenerate Oligonucleotide Primed PCR (DOP-PCR)
}

\author{
Nona Arneson, Simon Hughes, Richard Houlston, and Susan Done
}

This protocol was adapted from "PCR-Based Whole Genome Amplification," Chapter 18, in PCR (eds. Hughes and Moody). Scion Publishing Ltd., Oxfordshire, UK, 2007.

\section{INTRODUCTION}

PCR-based whole-genome amplification (WGA) has the goal of generating microgram quantities of genome-representative DNA from picogram or nanogram amounts of starting material. This amplification should introduce little, or ideally no, representational bias. Unlike other techniques for WGA, PCR-based methods are generally less affected by DNA quality and are more applicable to DNA extracted from various sources (fixed and fresh tissues). The degenerate-oligonucleotide-primed PCR (DOP-PCR) method described here allows complete genome coverage in a single reaction. In contrast to the pairs of target-specific primer sequences used in traditional PCR, only a single primer, which has defined sequences at its $5^{\prime}$-end (containing an Xhol restriction site) and $3^{\prime}$-end and a random hexamer sequence between them, is used here. DOP-PCR comprises two different cycling stages. In stage 1 (low stringency), low-temperature annealing and extension in the first five to eight cycles occurs at many binding sites in the genome. The $3^{\prime}$-end of the primer binds at sites in the genome complementary to the 6-bp well-defined sequence at the $3^{\prime}$-end of the primer $\left(\sim 10^{6}\right.$ sites in the human genome). The adjacent random hexamer sequence (displaying all possible combinations of the nucleotides A, G, C, and T) can then anneal and tags these sequences with the DOP primer. In stage 2 (high stringency; $>25$ cycles), the PCR annealing temperature is raised, which increases priming specificity during amplification of the tagged sequence. DOP-PCR generates a smear of DNA fragments (200-1000 bp) that are visible on an agarose gel.

\section{RELATED INFORMATION}

When implementing WGA in the laboratory, it is important to assess the entire experimental process closely, including sample collection, fixation, storage, and initial DNA extraction procedures, as all of these factors can affect DNA quality and thus have some bearing on the selection of the WGA technique. When using WGA, it is important first to validate the method selected and to become proficient in the technique before applying it to actual samples. Irrespective of the method selected, it is essential to establish that the results generated from the amplified DNA are indistinguishable from the results obtained from the original genomic DNA.

The DNA that can be amplified by PCR-based WGA includes DNA extracted from fixed, frozen, or archival tissue; whole blood; buccal swabs; single cells; sorted chromosomes; and laser-capture microdissected tissue (for microdissection of tissues embedded in paraffin, the sections must be deparaffinized prior to microdissection). Genomic DNA may be extracted using a variety of commercially available methods such as the QIAamp DNA mini-kit (QIAGEN). Fixation of tissues can introduce sequence variations and reduce overall DNA quality. When studying such tissues, prior examination of the DNA by agarose gel electrophoresis will help determine the DNA quality. The amplified DNA produced is suitable for a range of downstream genetic assays and thus has the 
potential for use not only in academic research, but also in commercial, forensic, and diagnostic laboratories.

DOP-PCR was first described by Telenius et al. (1992). Protocols for Whole-Genome Amplification by Improved Primer Extension Preamplification PCR (I-PEP-PCR), Whole-Genome Amplification by Single-Cell Comparative Genomic Hybridization PCR (SCOMP), Whole-Genome Amplification by Adaptor-Ligation PCR of Randomly Sheared Genomic DNA (PRSG), and GenomePlex Whole-Genome Amplification are also available in this issue of CSH Protocols.

\section{MATERIALS}

CAUTIONS AND RECIPES: Please see Appendices for appropriate handling of materials marked with $<!>$, and recipes for reagents marked with $<\mathbf{R}>$.

\section{Reagents}

Agarose (Sigma)

DNA size marker (100-bp ladder; Invitrogen)

dNTP mix (250 mM; Invitrogen)

DOP-PCR primer (5'-CCGA CTCGAG NNNNNNATGTGG-3') $(1 \mu \mathrm{M})$

$N$ represents $A, G, T$ or $C$. The Xhol site is highlighted in bold.

$<$ ! $>$ Ethidium bromide $(10 \mathrm{mg} / \mathrm{mL}$; Sigma)

Genomic DNA (5 ng/ $\mu \mathrm{L})$

It is important to determine the DNA concentration (in nanograms per milliliter) accurately. This can be done by using the RediPlate 96 PicoGreen dsDNA quantitation kit (or similar) in conjunction with a fluorescencebased microplate reader, or by using a standard spectrophotometer to take the absorbance reading at $260 \mathrm{~nm}$ and multiplying it by 50 and then by the dilution factor.

$\mathrm{H}_{2} \mathrm{O}$ (nuclease-free; Promega)

$\mathrm{MgCl}_{2}$ (50 mM; Invitrogen)

Orange loading dye (6X; Fermentas)

Taq DNA polymerase ( $5 \mathrm{U} / \mu \mathrm{L})$ and accompanying 10X PCR buffer (Invitrogen)

$<\mathrm{R}>\mathrm{TBE}$ buffer ( $1 \mathrm{X}$ diluted from a $10 \mathrm{X}$ stock at $\mathrm{pH} 8$; may also be obtained from Sigma)

Thermosequenase (5 $\mathrm{U} / \mu \mathrm{L}$ ) and accompanying 10X Thermosequenase buffer (GE Healthcare)

$<\mathrm{R}>$ Tris- $\mathrm{Cl}(10 \mathrm{mM}$ at $\mathrm{pH} 8.0)$ containing $0.1 \mathrm{mM}$ EDTA

\section{Equipment}

Electrophoresis apparatus

Thermal cycler (MJ Research)

\section{METHOD}

\section{Stage 1: Low-Stringency Cycling}

Low-stringency conditions allow low-temperature annealing and extension to occur at several binding sites across the genome.

1. Combine the following reagents:
$2 \mu \mathrm{L}$
Genomic DNA
$1 \mu \mathrm{L}$
10X Thermosequenase buffer
$1 \mu \mathrm{L}$
DOP-PCR primer
$0.1 \mu \mathrm{L}$
dNTP mix
$1 \mu \mathrm{L}$
Thermosequenase
Add nuclease-free $\mathrm{H}_{2} \mathrm{O}$ to a final volume of $10 \mu \mathrm{L}$. 
It is important to include a negative control, which includes all of the reaction constituents with the exception of DNA. It is also advisable to set up at least three reactions per sample (if there is sufficient DNA). This will provide enough amplified DNA to perform the required experiments and sufficient DNA for archiving.

2. PCR-amplify the sample(s) in a thermal cycler using the following conditions:

\begin{tabular}{lll} 
Number of cycles & Temperature & Time \\
\hline 5 & $94^{\circ} \mathrm{C}$ & $60 \mathrm{sec}$ \\
& $30^{\circ} \mathrm{C}$ & $60 \mathrm{sec}$ \\
& $\operatorname{Ramp}$ to $72^{\circ} \mathrm{C}$ & $>3 \mathrm{~min}\left(3.5^{\circ} \mathrm{C} / 15 \mathrm{sec}\right)$ \\
& $72^{\circ} \mathrm{C}$ & $2 \mathrm{~min}$ \\
& $72^{\circ} \mathrm{C}$ & $10 \mathrm{~min}$
\end{tabular}

3. Store the reaction mixtures at $-20^{\circ} \mathrm{C}$ for up to $3 \mathrm{~d}$, or proceed immediately to Step 4 .

\section{Stage 2: High-Stringency Cycling}

High-stringency conditions use an elevated annealing temperature, allowing more specific priming of the fragments tagged with the primer sequence.

4. Mix the following reagents for each sample:
$4 \mu \mathrm{L} \quad 10 X$ PCR buffer
$2 \mu \mathrm{L} \quad \mathrm{MgCl}_{2}$
$0.3 \mu \mathrm{L} \quad$ DOP-PCR primer
$1.6 \mu \mathrm{L} \quad$ dNTP mix
$0.4 \mu \mathrm{L} \quad$ Taq polymerase

Add nuclease-free $\mathrm{H}_{2} \mathrm{O}$ to a final volume of $40 \mu \mathrm{L}$.

5. Combine the reaction mixtures from Stage 1 (Step 3) and Stage 2 (Step 4).

6. PCR-amplify the sample(s) in a thermal cycler using the following conditions:

\begin{tabular}{lll} 
Number of cycles & Temperature & Time \\
\hline 30 & $94^{\circ} \mathrm{C}$ & $60 \mathrm{sec}$ \\
& $55^{\circ} \mathrm{C}$ & $60 \mathrm{sec}$ \\
& $72^{\circ} \mathrm{C}$ & $2 \mathrm{~min}$ \\
1 & $72^{\circ} \mathrm{C}$ & $10 \mathrm{~min}$
\end{tabular}

7. Determine the size of the products:

i. Mix $5 \mu \mathrm{L}$ of the reaction mix with $1 \mu \mathrm{L}$ of $6 \mathrm{X}$ orange loading dye solution.

ii. Resolve the aliquot by Agarose Gel Electrophoresis using a 1\% agarose gel containing $20 \mu \mathrm{g}$ of ethidium bromide $(10 \mathrm{mg} / \mathrm{mL})$ per $100 \mathrm{~mL}$ of agarose, alongside a DNA size marker.

The size of the amplification product depends on the quality of the starting DNA. If it is high-molecularweight DNA (extracted from fresh tissue or cells), the amplification product smear will range from 50 to $1500 \mathrm{bp}$. However, if the DNA is of low molecular weight (e.g., from fixed tissue), then the size of the amplification product smear will generally be $<500 \mathrm{bp}$.

The negative-control lane should not show any amplification. If it does, contamination may be present, and reactions must be repeated.

See Troubleshooting.

8. Purify the amplified DNA.

For some downstream applications, it may be necessary to both purify and quantify the amplified DNA before use. The choice of DNA purification procedure is up to the user. DNA yields of $\sim 4-6 \mu g$ are typically obtained in a $100-\mu L$ reaction.

Standard protocols for array comparative genomic hybridization (CGH) can be used, but when using amplified DNA, we recommend labeling 3-4 $\mu \mathrm{g}$ of DNA instead of the standard $1 \mu \mathrm{g}$.

See Troubleshooting. 


\section{TROUBLESHOOTING}

Problem: There is amplification in the negative control.

[Step 7.ii]

Solution: Due to the manipulation of PCR products in all PCR-based WGA methods, the reactions can easily be contaminated. If negative controls produce a DNA smear, several steps can be tried to eliminate this:

- Repeat using fresh reagents.

- Use filtered tips to avoid introduction of contaminants via aerosol from the pipette.

- Physically separate the areas in the laboratory where reactions are set up. Prepare and pipette the PCR mixture at one bench, and then add the DNA to the reaction in a different location in the laboratory. Also, use different pipettes for reaction preparation and pipetting of DNA.

- Aliquot all reaction constituents; if an aliquot becomes contaminated, only that aliquot will be lost and not the entire stock.

Problem: Unpredictable amplification is observed.

[Step 7.ii]

Solution: A positive control (such as starting with $50 \mathrm{ng}$ of good-quality genomic DNA) can be used to ensure that the reaction is working optimally. In addition:

- Store small aliquots of dNTPs and oligonucleotides, as repeated freeze/thaw cycles of a single stock can affect the integrity of these reagents and thereby affect the efficiency of WGA.

- The starting concentration of DNA is crucial. Best results are obtained when starting with $10 \mathrm{ng}$ (or more) of DNA extracted from fresh tissue/blood or $100 \mathrm{ng}$ of DNA extracted from fixed tissue. Lower amounts of DNA ( $<10 \mathrm{ng}$ from fresh tissue or $<100 \mathrm{ng}$ from fixed tissue) will generate amplification products, but results obtained in downstream applications may not be faithful to the result that would have been obtained from nonamplified DNA.

- If a positive control PCR using 10-100 ng of good-quality, high-molecular-weight DNA produces good results, the assay problems are a product of the DNA sample under investigation. However, if the positive control does not amplify, it suggests a problem with the reaction constituents or the thermal cycling. In such cases, use fresh aliquots of reagents, and repeat the experiment. If the problem still persists, it may be necessary to order fresh reagents.

Problem: The amplification smear contains smaller DNA fragments than expected.

[Step 7.ii]

Solution: The efficiency of amplification is dependent on the quality of the starting DNA, and the size of the amplification products is also template-dependent. Tissue fixation causes degradation of template DNA within the sample. If the template is degraded, as is DNA from formalin-fixed, paraffin-embedded material, the smear will be smaller in size. Unfortunately, there is no way of improving this; thus care must be taken when using such products for downstream applications, because there may be more bias in these samples. Although PCR-based WGA is tolerant to mild or moderate DNA degradation and will amplify DNA with an average length of $\sim 200 \mathrm{bp}$, in this case it is essential to use increased quantities of starting DNA (100 ng) to guarantee a satisfactory yield of final product. Moderate to severe degradation will reduce WGA efficiency and subsequently decrease the quality of results obtained in downstream applications.

Problem: There is insufficient DNA for downstream reactions.

[Step 8]

Solution: Combine at least two individual WGA amplifications (Step 1) for each DNA to be studied, as this produces better results in downstream experiments.

Problem: Unpredictable results are obtained from downstream applications.

Solution: Successful PCR-based WGA and successful downstream results depend on the quality of starting DNA. For instance, if there is ineffective PCR amplification of a specific control gene with nonamplified DNA, negative results after WGA are to be expected. If using laser-capture microdissected 
material, perform a standard control PCR and a PCR using DNA from nonlaser-capture microdissected tissue prior to WGA. In some cases, it may be necessary to try different amounts of amplified DNA in downstream PCR amplification procedures, for example, 12, 25, 50, and $100 \mathrm{ng}$.

\section{DISCUSSION}

DOP-PCR-amplified DNA has been widely used, but precise measurement of the amount of starting template DNA is important. A shortage of genomic DNA template sometimes leads to a lower reliability of results in downstream applications due to allele drop-out and representational bias. Good results have been obtained for array CGH (Peng et al. 2003), for which DOP-PCR has been demonstrated to provide the most reliable results when using minute quantities of DNA ( $\mathrm{Ng}$ et al. 2005). Single-nucleotide polymorphism (SNP) typing (Bannai et al. 2004) and microsatellite genotyping (Cheung and Nelson 1996) have demonstrated that a large proportion of the genome can be amplified by DOP-PCR. However, there is some debate as to whether there is preferential amplification of shorter alleles (Grant et al. 2002). It is important to take these points into consideration when using DOP-PCR-amplified DNA.

\section{REFERENCES}

Bannai, M., Higuchi, K., Akesaka, T., Furukawa, M., Yamaoka, M., Sato, K., and Tokunaga, K. 2004. Single-nucleotide-polymorphism genotyping for whole-genome-amplified samples using automated fluorescence correlation spectroscopy. Anal. Biochem. 327: 215-221.

Cheung, V.G. and Nelson, S.F. 1996. Whole genome amplification using a degenerate oligonucleotide primer allows hundreds of genotypes to be performed on less than one nanogram of genomic DNA. Proc. Natl. Acad. Sci. 93: 14676-14679.

Grant, S.F., Steinlicht, S., Nentwich, U., Kern, R., Burwinkel, B., and Tolle, R. 2002. SNP genotyping on a genome-wide amplified DOP-PCR template. Nucleic Acids Res. 30: e125 $10.1093 /$ nar/gnf125.
Ng, G., Roberts, I., and Coleman, N. 2005. Evaluation of 3 methods of whole-genome amplification for subsequent metaphase comparative genomic hybridization. Diagn. Mol. Pathol. 14: 203212.

Peng, D.F., Sugihara, H., Mukaisho, K., Tsubosa, Y., and Hattori, T. 2003. Alterations of chromosomal copy number during progression of diffuse-type gastric carcinomas: Metaphase- and arraybased comparative genomic hybridization analyses of multiple samples from individual tumours. J. Pathol. 201: 439-450.

Telenius, H., Carter, N.P., Bebb, C.E., Nordenskjold, M., Ponder, B.A., and Tunnacliffe, A. 1992. Degenerate oligonucleotide-primed PCR: General amplification of target DNA by a single degenerate primer. Genomics 13: 718-725. 


\section{Whole-Genome Amplification by Degenerate Oligonucleotide Primed PCR (DOP-PCR)}

Nona Arneson, Simon Hughes, Richard Houlston and Susan Done

Cold Spring Harb Protoc; doi: 10.1101/pdb.prot4919

\begin{tabular}{cc}
\hline $\begin{array}{r}\text { Email Alerting } \\
\text { Service }\end{array}$ & Receive free email alerts when new articles cite this article - click here. \\
\hline $\begin{array}{c}\text { Subject } \\
\text { Categories }\end{array}$ & Browse articles on similar topics from Cold Spring Harbor Protocols. \\
& Amplification of DNA by PCR (85 articles) \\
& Bioinformatics/Genomics, general (192 articles) \\
& DNA Sequencing (96 articles) \\
& Genetic Variation (86 articles) \\
& Genetics, general (374 articles) \\
& Genome Analysis (191 articles) \\
& Genomic DNA (135 articles) \\
& Genomic Libraries (66 articles) \\
& Libraries (147 articles) \\
& Libraries, general (113 articles) \\
& Molecular Biology, general (1293 articles) \\
& Polymerase Chain Reaction (PCR) (139 articles) \\
& Polymerase Chain Reaction (PCR), general (184 articles) \\
& \\
&
\end{tabular}

